\title{
FELSŐOKTATÁSI SZAKKÉPZÉSBEN RÉSZTVEVŐK MUNKÁHOZ KAPCSOLÓDÓ ÉRTÉKVILÁGA
}

\author{
Miklós Péter
}

\begin{abstract}
Absztrakt: A szegedi felsőoktatási szakképzésben résztvevők munkához kapcsolódó értékvilágát vizsgáló felmérés (2013) során a szerző a Donald E. Super által kidolgozott munka-érték kérdőív rövidített változatát használta. A Szegedi Tudományegyetem felsöoktatási szakképzésben résztvevő hallgatóinak értékstruktúráját vizsgálva látszik, hogy számukra kiemelkedően fontos a jó munkahelyi légkör, ugyanakkor azt is megállapíthatjuk, hogy az anyagiak és az intellektuális értékek is számítanak nekik. Jellemzỏ rájuk, hogy tanulmányaikat nem szeretnék befejezni ezen a szinten. Érdekes azonban, hogy az altruizmus mindössze az ötödik helyre került a hat értékkör közül.
\end{abstract}

Abstract: The bases of the survey (2013) was the shortened version of the questionnaire made by Donald E. Super. For students of the higher education qualification programmes in the University of Szeged important the great workplace atmosphere, furthermore material and intellectual values. They don't want to complete their studies at this level. However, it's interesting that altruism is just the last but one value for them.

Kulcsszavak: munkaerőpiac, szakképzés, értékek, ifjúság, pályatervezés

Keywords: labour market, qualification training, values, youth, career planning

\section{A munkához kapcsolódó értékvilág kutatásának lehetőségei}

A történeti dimenzióban is vizsgált társadalomfejlödés során az emberi tudatban a munka - szó szerint értelmezve - értékként él, amelynek a történelem folyamán volt negatív (a középkori, a szabadságot korlátozó kényszerített és parancsolt jellegtől az Isten országának evilági építésének víziójáig) és pozitív (a kapitalista és a szocialista rendszerekben egyaránt alkalmazott azonosítása a szorgalmas, törekvő dolgozónak és a boldog, sikeres embernek) töltete egyaránt.

A munkához kapcsolódó értékstruktúráról Hankiss Elemér véleménye, hogy az egyénnek, a társadalomnak és a politikai rendszernek feladata egyrészt „a létfenntartó munkát létkiteljesítő mozzanatokkal átszőnie”, másrészt „a munka jelentését ki kell terjesztenie és a létkiteljesítő, közvetlenül személyiség- és közösséggazdagító tevékenységeket is belé kell foglalnia". (Hankiss, 1977: 371)

Csirszka János szerint „az emberi munka egyik lényeges kritériuma, hogy értékeket valósít meg." A munka (ami ebben is hasonlatos a játékhoz) ugyanis szemben a rombolással - mindig célorientált tevékenység, amelynek végső célja valamilyen új érték előállítása, legyen az fizikailag megnyilvánuló és kézzel fogható (mint például a munkapad mellett sorakozó termékek, vagy a kifestett szoba), vagy éppen elvontabb, szellemi termék (mint például az oktatás vagy a tanácsadás, amely többnyire verbális és kognitív folyamat). Az egészséges lelkületü ember számára a munka alkotó és alakító szükségleteinek kielégítése, aki számára az egyik legnagyobb próbatétel és kihívás a munkátlanság, a munkanélküliség (Csirszka, 1985).

Csirszka elméletében az életpálya (ami a „foglalkozás időbeli megvalósulásának lényege szerint körülhatárolt és lehetőségeiben kijelölt útja") és a hivatás (ami a 
„személyiség egyéni életének értelmét kifejezo, személyazonosuláson alapuló vállalás és elkötelezettség”) mindig értékeken alapul, s szerinte „bármely igaz érték kimunkálása értelmet adhat az ember pályájának". Ilyen - önmagában szükséges, de nem elégséges - érték lehet az életfenntartás biztosításának, vagy a pénz mint eszközérték megszerzésének igénye. Magasabb szintje a hivatáseszménynek amelynek alapja a valamilyen eszményt képviselő értékkel való azonosulás - az életpályába való integrálása (Csirszka, 1985).

A munkához, mint emberi tevékenységhez elválaszthatatlanul tartoznak etikai járulékok is. Ezek a munkaerkölcsben - ami nem más, mint a személyiségnek a munkában megnyilvánuló értékelő és értékmegvalósító megnyilvánulása ragadhatóak meg, amelynek két pszichológiai jellemzője van. Az egyik a munkaértékekkel való azonosulás, a másik az erkölcsi elvek gyakorlati megvalósítása.

A munkatevékenység során erkölcsileg kritikus helyzetek leginkább az anyagi felelösség, az ember iránti felelősség és a munkaerkölcsi felelösség területén alakulnak ki. Ez utóbbin azt a követelményt értjük, amely elvárja a felmerülő hibalehetöségekkel és kockázati tényezökkel szemben a helyes erkölcsi cselekvés megvalósítását (Csirszka, 1977).

A munkavégzés során, illetve a munkahely szociális jelenségvilágában számos - vélt vagy valós - etikai konfliktushelyzet okoz kihívást a munkavállalóknak (Gulyás, 2008). A beválás szempontjából egyáltalán nem mellékes munkaerkölcsi készségek és pszichológiai jellemzők empirikus vizsgálatára is van lehetőség, például Gáspárné Zauner Éva mondásválasztásos vizsgálataival. (G. Zauner, 1978).

A munkához kapcsolódó magyarországi empirikus értékkutatások az 1960-as években indultak meg. Egyik első programja volt a Hankiss Elemér vezetésével az ipari munkásság értékrendjének bizonyos dimenzióiról készült felmérés az 1970-es évek elején, amelynek fö módszere a statisztikai elemzés és a strukturált interjú volt. (Hankiss, 1976) B. Vörös Gizella az 1970-es évek végén a fiatal szakmunkások értékrendszerét - föleg interjúkon keresztül, a társadalmi és politikai kérdésekre fókuszálva - vizsgálta. (B. Vörös, 1980.).

„Érték és munka” címmel állított össze kötetet Szilágyi Klára, amelynek szerzői Donald E. Super munkaérték kérdöívét használták, $s$ amelyben Schüttler Tamás a pályaválasztás elött álló középiskolások, Szilágyi Klára a tanulmányaikat befejezö föiskolai hallgatók és a felsőoktatás elsőéves hallgatóinak, Benson Katalin az orvostanhallgatók, Rókusfalvy Pál a testnevelési főiskola diákjainak, Dancs István a szakmunkástanulók és a szakközépiskolások értékválasztásait és értékorientációját elemezte. (Szilágyi [szerk.], 1987)

Szilágyi Klára később a pedagóguspályán megfigyelhető értékválasztásról és értékközvetítésről írt munkájában az értékfeltárás stratégiáit, valamint az értékfeltáró foglalkozások lehetőséges tematikáját is bemutatta. (Szilágyi, 1991)

\section{Felsőoktatási szakképzésben résztvevők munkához kapcsolódó értékvilága}

A vizsgálatok során a Donald E. Super által kidolgozott munka-érték kérdőív Szilágyi Klára által összeállított rövidített, tizennyolc kérdésböl álló és hat átfogó 
értékkört vizsgáló változatát használtam. Donald E. Super munka-érték kérdőívének rövidített változata az alábbi hat értékkört vizsgálja (Szilágyi, 2007 alapján).

- Intellektuális értékek. Akik számára ezek fontosak, azok olyan munkahelyet szeretnének, ahol nem a kezüket, hanem inkább a fejüket használhatják, szeretnek problémákat megoldani, összefüggésekre rájönni, s örömmel használják kreativitásukat. Érték számukra a szellemi tevékenység és az alkotás.

- Vezetés, irányítás. Munkahelyükön szeretnek másokért felelösséget vállalni, mások munkáját szervezni, utasításokat adni, összetettebb folyamatokat átlátni, emberekkel kapcsolatot tartani. Érték számukra, ha másokat irányíthatnak, s ha mások hozzájuk fordulnak segítségért.

- Altruizmus. Az ilyen értékkört magukénak vallók szeretnek másokon segíteni: dolgozni értük és gondoskodni róluk. Érték nekik a másokért való felelősségvállalás és a személyes segítő kapcsolat, amely már önmagában munkájuk jutalma, s azért anyagi megbecsülést és ellenszolgáltatást kevésbé várnak.

- Jó munkahelyi légkör. Akik ezt az értékkört preferálják azoknak fontos a munkahelyi szociális jelenségvilágban a kellemes baráti légkör, ahol a vezető is csak az egyik csapattagként van számon tartva, ahol a munkaidő végeztével nem szakad meg az emberi kapcsolat, ahol közösen örülnek a sikereknek és közösen vállalják a felelösséget az esetleges kudarcokért.

- Anyagiak. Azok, akiknek fontos, hogy sok pénzt keressenek, olyan munkahelyet szeretnének találni, ahol magas a bér és lehetőség szerint vannak egyéb juttatások is. Gyakran vállalnak teljesítménybérezést vagy jutalékrendszeren alapuló kompenzációt, s fontosak számukra a munkahelyi kedvezmények (például ruhapénz, vagy kedvezményes vásárlási lehetőség) és presztízstárgyak (számítógép, telefon, autó stb.).

- Kötetlenség. Fontos számukra, hogy kevés szabály legyen munkahelyükön, $s$ kevés legyen a kötöttség úgy a munkaidő, mint a munkafeladatok tekintetében. Nem fontos számukra a határidő, viszont a teljesítmény az lehet. Szeretik munka közben jól érezni magukat, $s$ néha az alapvető szabályok betartása is nehéz lehet nekik.

A felsőoktatási szakképzésben résztvevők munkához kapcsolódó értékvilágát a fenti módszertan szerint vizsgáló felmérésem során az adatfelvételre 2013 novemberében került sor: a Szegedi Tudományegyetem Juhász Gyula Pedagógusképző Kara Szakképzési, Távoktatási és Továbbképzési Központjának ötven darab felsőoktatási szakképzésben résztvevő hallgatójától. A kérdőívek összesítése után az adatokat táblázatkezelö és diagrameszközök alkalmazásainak segítségével ábrázoltam és jelenítettem meg grafikusan. Az alábbiakban ezen vizsgálat eredményeit ismertetem, valamint az azok alapján levonható következtetéseket fogalmazom meg. 
1. ábra: A felsőoktatási szakképzésben résztvevő megkérdezett hallgatók nemek szerinti megoszlása (2013) $\mathrm{N}=50$

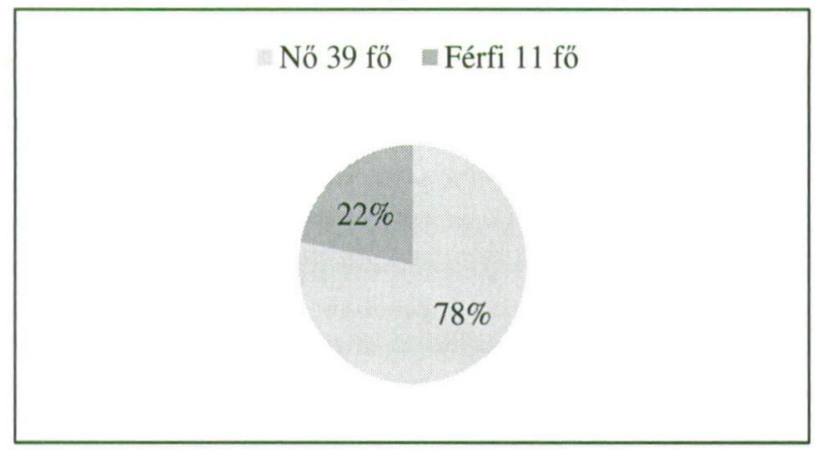

Forrás: saját szerkesztés

A Szegedi Tudományegyetem Juhász Gyula Pedagógusképző Karán felsőoktatási szakképzésben tanuló, a vizsgálat során megkérdezett hallgatók hetvennyolc százaléka (39 fö) nő, a férfiak aránya huszonkét százalék (11fö). Életkorukat tekintve valamennyien tizennyolc és harmincöt év közöttiek. A legmagasabb iskolai végzettséget vizsgálva megállapítható, hogy nyolcvan százalékuknak (40fö) érettségi bizonyítvány, húsz százalékuknak viszont egyetemi, illetve föiskolai diploma igazolja a már befejezett tanulmányaik szintjét (szakmunkás végzettsége, illetve korábban szerzett szakképesítése egyiknek sincs).

2. ábra: A felsőoktatási szakképzésben résztvevő megkérdezett hallgatók legmagasabb iskolai végzettsége (2013) $\mathrm{N}=\mathbf{5 0}$

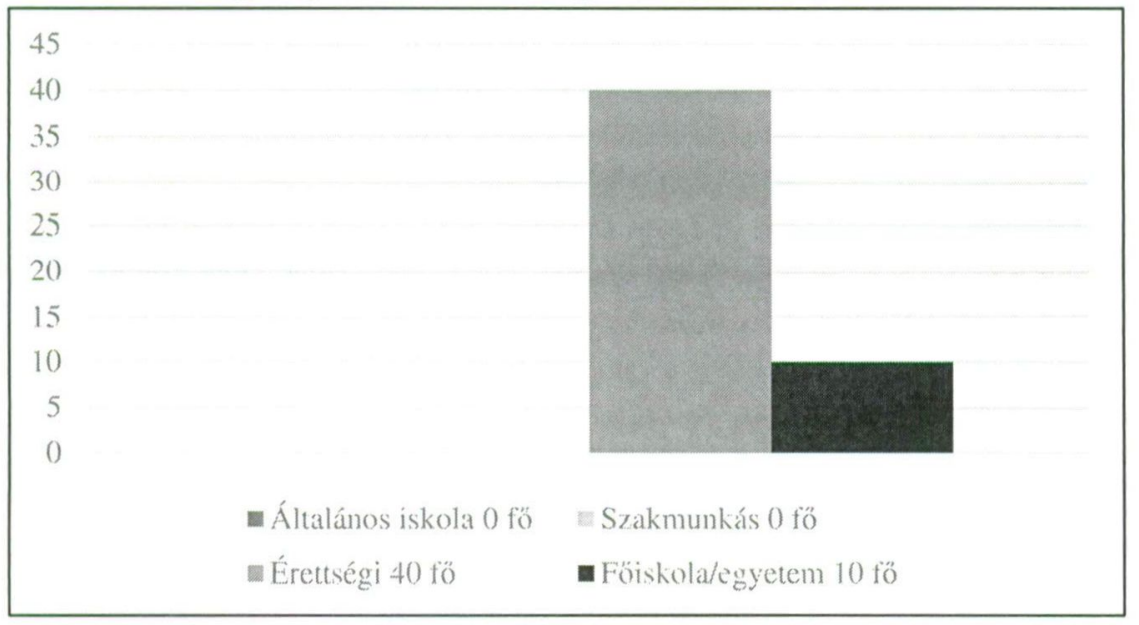

Forrás: saját szerkesztés

A csoport vizsgált értékköreit nézve kiderül, hogy a megkérdezett hallgatók számára a legfontosabb munkához kapcsolódó érték a jó munkahelyi légkör $(13,0)$, de nem sokkal marad le ettől az anyagiak $(12,6)$ és a szellemi kihívások igénye $(12,6)$, valamint a másokon való segítés $(12,2)$ és a kötetlenség, szabályoktól való 
minél magasabb szintü mentesülés $(12,5)$ igénye sem. Ebben a csoportban a vezetés és irányítás értékköre kapta a legkevesebb pontot $(9,6)$.

\section{1. táblázat: A felsőoktatási szakképzésben résztvevő megkérdezett hallgatók munkához kapcsolódó értékei (2013) N=50}

\begin{tabular}{|l|c|}
\hline \multicolumn{1}{|c|}{ Érték } & Pontszám (0-15) \\
\hline Intellektuális értékek & 12,6 \\
\hline Vezetés, irányítás & 9,6 \\
\hline Altruizmus & 12,2 \\
\hline Jó munkahelyi légkör & 13,0 \\
\hline Anyagiak & 12,6 \\
\hline Kötetlenség & 12,5 \\
\hline
\end{tabular}

Forrás: saját szerkesztés

\section{Konklúzió}

A Szegedi Tudományegyetem felsőoktatási szakképzésben résztvevő hallgatóinak értékstruktúráját vizsgálva látszik, hogy számukra kiemelkedően fontos a jó munkahelyi légkör, ugyanakkor azt is megállapíthatjuk, hogy az anyagiak és az intellektuális értékek szintén számítanak nekik. Egyetemi hallgatóktól - még ha „csak" felsőoktatási szakképzésben résztvevők is - talán nem különös, hogy értéknek tartják azt, hogy használhatjuk az eszüket, s az sem meglepö, hogy szakképzettségük birtokában jól szeretnének keresni.

Jellemző rájuk, hogy tanulmányaikat nem szeretnék befejezni, hanem bachelor képzésben folytatnák (sőt többen vesznek részt a felsőoktatási szakképzés mellett alap [BA/BSc], vagy mester [MA/MSc] szintü tanulmányokban), illetve rendelkeznek diplomával. Így tehát szeretik az szellemi adottságaikat és képességeiket használni, amit a tanulás iránti elkötelezettségükkel is bizonyítanak.

Érdekes azonban, hogy az altruizmus mindössze az ötödik helyre került a hat értékkör közül. Ez egyrészt lehet a jele annak, hogy kevés munkatapasztalattal rendelkeznek (legtöbben alkalmi diákmunkát végeztek), így nem tudják, milyen másokon segítve dolgozni, másrészt pedig rámutathat arra, hogy ennek a generációnak a tudatában már nem akkora érték a másokon való segítés, mint a megelőző nemzedékek számára. 


\section{Irodalomjegyzék}

B. Vörös G. (1980): Fiatal szakmunkások értékrendszere. Eredmények és módszerek. Müvelödéskutató Intézet, Budapest.

Csirszka J. (1977): Munka- és pályaalkalmasság pszichológiája. ELTE BTK, Budapest.

Csirszka J. (1985): A személyiség munkatevékenységének pszichológiája. Akadémiai Kiadó, Budapest.

G. Zauner É. (1978): Mondásválasztás. Pedagógiai-pszichológiai módszer a személyiség értékrendszerének megismerésére. Akadémiai Kiadó, Budapest.

Gulyás L. (2008): A munkakörnyezet kérdésköre. In: Gulyás László (szerk.) (2008): A humán erōforrás menedzsment alapjai. JATE Press - Szegedi Egyetemi Kiadó, Szeged, 189-206.

Hankiss E. (1976): Értékszociológiai kísérlet. Az ipari dolgozók néhány rétegének értékrendjérōl. Népmủvelési Propagandairoda, Budapest.

Hankiss E. (1977): Érték és társadalom. Tanulmányok az értékszociológia köréböl. Magvető Könyvkiadó, Budapest.

Szilágyi K. (1987): A Super-féle munkaérték kérdőív. In: Szilágyi K. (szerk.): Érték és munka. A munkához kapcsolódó értékek vizsgálatának tapasztalatai a felsöoktatásban. Oktatáskutató Intézet, Budapest, 7-33.

Szilágyi K. (1991): Értékválasztás, értékközvetítés a pedagóguspályán. Oktatáskutató Intézet, Budapest.

Szilágyi K. (2007): Munka-pályatanácsadás professzió. Kollégium Kft., Budapest.

Szilágyi K. (2012): Karrier- és pályatervezés. Módszertani útmutató csoportvezetók számára. Kollégium Kft., Budapest.

Szilágyi K. (szerk.) (1987): Érték és munka. A munkához kapcsolódó értékek vizsgalatának tapasztalatai a felsőoktatásban. Oktatáskutató Intézet, Budapest. 